\title{
IDENTIFIKASI DAN UJI KANDUNGAN METABOLIT SEKUNDER TUMBUHAN
} OBAT

\author{
Ridwan $^{1 *}$, La Ode Kaharudin ${ }^{2}$ \\ ${ }^{1,2}$ Program Studi Pendidikan Biologi Universitas Muslim Buton, Indonesia \\ ${ }^{*}$ Koresponden Penulis : ridwan071093@gmail.com
}

\begin{abstract}
ABSTRAK
Tanaman obat adalah sumber penting yang mudah diakses untuk digunakan sebagai perawatan kesehatan bagi masyarakat pedesaan. Tumbuhan dengan nilai obat dan senyawa pengobatan tradisional telah banyak mendapat perhatian dari para peneliti. Tanaman dapat berkhasiat obat karena adanya kandungan metabolit sekunder yang dimiliki. Penelitian menggunakan sampel tanaman Embelia sp. yang dimanfaatkan sebagai obat demam dan penurun panas oleh masyarakat Buton Utara serta Tetracera indica (Christm. \& panz. Merr.) sebagai obat tekanan darah tinggi. Penelitian bertujuan untuk mengetahui jenis tanaman obat dan kandungan metabolit sekunder yang terkandung tanaman tersebut. Penelitian dilakukan melalui beberapa tahapan diantaranya : tahap identifikasi, selanjutnya tahap uji kandungan metabolit sekunder yang dianalisis melalui beberapa tahap yaitu ektraksi, uji flavonoid, uji alkaloid, uji steroid / terpenoid, uji tanin, uji saponin dan uji fenol. Kandungan metabolit sekunder diuji masing-masing pada tiga bagian organ tanaman yang meliputi akar, batang dan daun. Hasil penelitian menujukkan bahwa tanaman yang diidentifikasi dalam penelitian tergolong spesies Embelia sp. dan Tetracera indica (Christm. \& panz. Merr.). Hasil uji metabolit sekunder menunjukkan bahwa akar dan batang Embelia sp. mengandung alkaloid, flavonoid, terpenoid, tanin, dan fenol. Akar, batang dan daun Tetracera indica (Christm. \& panz. Merr.) mengandung alkaloid, terpenoid, saponin, tanin, dan fenol. Kandungan flavonoid pada Embelia sp. memungkinkan tanaman tersebut dapat berperan sebagai obat demam dan penurun panas bagi masyarakat Buton Utara. Selanjutnya, kandungan terpenoid pada Tetracera indica (Christm. \& panz. Merr.) memungkinkan tanaman dapat digunakan sebagai obat tekanan darah tinggi.
\end{abstract}

Kata kunci: Embelia sp., Tetracera indica (Christm. \& panz. Merr.), Obat tradisional.

\begin{abstract}
Medicinal plants are an important, easily accessible resource for use as health care for rural communities. Plants with medicinal value and traditional medicinal compounds have received much attention from researchers. Plants can have medicinal properties because of their secondary metabolite content. The study used plant samples of Embelia sp. which is used as a medicine for fever and fever by the people of North Buton and Tetracera indica (Christm. \& panz. Merr.) as a medicine for high blood pressure. This study aims to determine the types of medicinal plants and the content of secondary metabolites contained in these plants. The research was carried out through several stages including: identification stage, then the secondary metabolite content test stage which was analyzed through several stages, namely extraction, flavonoid test, alkaloid test, steroid / terpenoid test, tannin test, saponin test and phenol test. The content of secondary metabolites was tested on three parts of the plant organs, which include roots, stems and leaves. The results showed that the plants identified in the study belonged to the species Embelia sp. and Tetracera indica (Christm. \& panz. Merr.). The secondary metabolite test results showed that the roots and stems of Embelia sp. contains alkaloids, flavonoids, terpenoids, tannins, and phenols. The roots, stems and leaves of Tetracera indica (Christm. \& panz. Merr.) contain alkaloids, terpenoids, saponins, tannins, and phenols. The flavonoid content in Embelia sp. This allows the plant to act as a fever medicine and fever reducer for the people of North Buton. Furthermore, the terpenoid content in Tetracera indica (Christm. \& panz. Merr.) allows the plant to be used as a medicine for high blood pressure.
\end{abstract} Keywords: Embelia sp., Tetracera indica (Christm. \& panz. Merr.), traditional medicine. 


\section{Pendahuluan}

Keanekaragaman hayati Indonesia menempati peringkat ke-3 di dunia setelah Brazil dan Zaire. Indonesia menjadi rumah bagi 30.000 dari 40.000 tanaman obat herbal di dunia, tanaman obat di Indonesia dikenal sebagai "Tanaman Biofarmaka" yang berarti tanaman yang berguna untuk pengobatan. Peran tumbuhan obat sebagai obat tradisional di Indonesia selalu menjadi bagian budaya yang diwariskan secara turun-temurun. Selama berabad-abad, masyarakat adat Indonesia mengembangkan obat tradisional dari tumbuhan yang diidentifikasi oleh nenek moyang untuk menyembuhkan penyakit dan menjaga Kesehatan. Secara umum, di Indonesia terdapat sekitar 30.000 jenis tanaman obat dan berpotensi untuk dikembangkan sebagai produk herbal yang memiliki kualitas setara dengan obat-obatan modern [1].

Tanaman obat adalah sumber penting yang mudah diakses untuk digunakan sebagai perawatan kesehatan bagi masyarakat pedesaan. Tumbuhan dengan nilai obat dan senyawa pengobatan tradisional telah banyak mendapat perhatian dari para peneliti. Ada tiga alasan utama yang mendorong penelitian tentang tanaman obat. Alasan tersebut diantaranya : pertama tumbuhan obat kebanyakan berasal dari salah satu jenis hutan bukan kayu produksi, hal ini dapat mengurangi penebangan di hutan. Kedua, Tanaman obat lebih mudah di dapat dan cenderung lebih murah jika dibandingkan dengan obat modern bagi masyarakat pedesaan. Alasan ketiga yaitu masyarakat lokal yang tinggal di dalam dan sekitar hutan memiliki tradisi pengetahuan atau kearifan lokal tentang pemnfaatan tumbuhan obat untuk mengobati berbagai penyakit. Dilihat dari habitusnya tumbuhan yang dimanfaatkan sebagai sumber obat terdiri dari pohon seperti kina (Cinchona merah), paku-pakuan seperti paku ajer (Angiopteris amboinensis), semak seperti dan rerumputan [2][3].

Sejarah pengobatan menggunakan tanaman berawal dari masa lalu ketika pengobatan herbal adalah satu-satunya jawaban atas semua jenis penyakit. Penyembuhan dengan tanaman obat telah digunakan sejak keberadaan manusia. Hubungan antara manusia dengan pencarian akan obat-obatan di alam sudah sejak lama, hal ini telah dibuktikan dari berbagai sumber seperti dokumen tertulis, awetan, dan bahkan obat-obatan tanaman asli. Kesadaran akan penggunaan tanaman obat merupakan hasil dari perjuangan bertahun-tahun melawan penyakit, yang darinya manusia belajar menggunakan obat dari kulit kayu, biji, tubuh buah dan bagian lain dari tanaman. Berbagai obat dari tumbuhan yang dikenal oleh peradaban kuno dan telah digunakan sejak ribuan tahun telah dimasukkan dalam farmakoterapi modern. Pengetahuan tentang perkembangan pemikirian tentang pemanfaatan tanaman obat serta evolusi kesadaran telah meningkatkan kemampuan para ilmuwan untuk menjawab tantangan yang muncul [4].

Penelitian ini menggunakan dua jenis tumbuhan yang diperoleh dari hutan di wilayah Buton Utara. Tumbuhan yang diidentifikasi telah digunakan masyarakat lokal sejak lama untuk mengobati demam pada anak dan mengobati tekanan darah tinggi. Namun, hal tersebut belum di dukung bukti ilmiah, karena belum adanya penelitian yang melaporkan terkait tanaman tersebut. Perlunya identifikasi tanaman untuk mengetahui jenis tanaman dan diperlukan uji fitokimia untuk memperoleh informasi terkait kandungan pada tanaman.

\section{Bahan dan Alat}

Bahan yang digunakan dalam penelitian ini adalah sampel tanaman (akar, batang dan daun), akuades, heksana, etil asetat, $\mathrm{HCL}$, Etanol 70\%, HCL 2N, Asam asetat, $\mathrm{H}_{2} \mathrm{SO}_{4}, \mathrm{FECl}_{3}$, larutan dragendorf, kertas saring, kertas label. Alat yang digunakan pada penelitian ini meliputi : gelas ukur, 
e-Jurnal Ilmiah BIOSAINTROPIS (BIOSCIENCE-TROPIC)

Volume 7/ No.: 2 / Halaman 46 - 56 / Januari Tahun 2022

ISSN : 2460-9455 (e) - 2338-2805(p)

Erlenmeyer, pipet tetes, pipet volum, beaker, timbangan analitik, tabung reaksi, hot plate, Shaker inkubetor, pinset, spatula dan rak tabung.

\section{Cara Kerja}

\section{Identifikasi Tanaman}

Identifikasi tanaman pada penelitian ini melalui beberapa proses diantaranya :

1. Kunci Determinasi

determinasi dilakukan dengan cara memperkecil lingkup kelompok tumbuhan yang diidentifikasi. Tumbuhan tersebut dikelompokkan berdasarkan ciri-ciri morfologi.

2. Membandingkan Spesimen

Pada tahap ini tumbuhan dibandingkan dengan spesimen tumbuhan lain yang dapat berupa herbarium. Perbandingan juga dilakukan dengan menggunakan buku acuan .

3. Menulis Deskripsi Tumbuhan Tumbuhan yang dideskripsikan menggunakan buku acuan ditulis dalam buku catatan. Catatan disimpan untuk dijadikan sebagai laporan pendukung.

4. Pendapat Ahli

Tahap terakhir yang dilakukan yaitu meminta pendapat ahli yang berkompeten dibidang tumbuhan. Hasil yang diperoleh dicatat dan didokumentasikan.

\section{Uji Fitokimia}

Uji fitokimia pada penelitian ini dilakukan pada masing-masing organ tanaman dengan menggunakan tiga jenis pelurut. Pelarut tersebut meliputi alkohol, etil asetat dan heksana. Tahapan uji fitokimia melalui beberapa tahapan diantaranya :

\section{Ekstraksi}

Ekstraksi dilakukan masing-masing pada dua jenis tumbuhan yang terdiri dari akar, batang dan daun. Organ tumbuhan dari kedua jenis tumbuhan dihaluskan dan dikeringkan. Sebanyak $10 \mathrm{~g}$ serbuk organ tumbuhan dimasukkan ke dalam gelas kimia, lalu ditambahkan $60 \mathrm{~mL}$ alkohol, $60 \mathrm{~mL}$ heksana dan $60 \mathrm{~mL}$ alkohol selanjutnya diinkubasi selama 3 hari. Tahap selanjutnya disaring menggunakan kertas saring, filtrat yang diperoleh dipekatkan dengan cara diuapkan dengan vacuum rotary evaporator untuk menghasilkan ekstrak kental masing-masing pelarut. Ekstrak kental kemudian diuji lebih lanjut.

\section{Uji Flavonoid}

Uji flavonoid dilakukan masing-masing pada organ tumbuhan dengan cara $1 \mathrm{~mL}$ sampel dicampur dengan $1 \mathrm{~mL}$ etanol 70\%. Selanjutnya ditambahkan $0,1 \mathrm{~g}$ serbuk $\mathrm{Mg}$ dan 10 tetes HCL pekat dan dihomogenkan menggunakan vortex. Uji positif flavonoid ditunjukkan dengan perubahan warna merah, kining dan jingga.

\section{Uji Alkaloid}

Uji alkaloid dilakukan masing-masing pada organ tumbuhan dengan cara mencampurkan $10 \mathrm{~mL}$ sampel dengan 1,5 mL HCL 2N. Selanjutnya dipanaskan selama 5 menit lalu disaring menggunakan kertas saring. Hasil saringan ditambahkan 5 tetes pereaksi dragendorff, hasil uji positif alkaloid ditunjukkan dengan warna orange atau jingga. 


\section{Uji steroid dan terpenoid}

Uji terpenoid dilakukan dilakukan masing-masing pada organ tumbuhan (dengan cara mencampurkan $1 \mathrm{~mL}$ sampel dengan 5 tetes asam asetat alhidrat lalu dihomogenkan menggunakan vortex. Selanjutnya ditambahkan dengan 2 tetes $\mathrm{H} 2 \mathrm{SO} 4$ pekat. Terbentuknya warna hijau biru pada sampel menunjukkan adanya kandungan steroid dan terbentuknya warna merah menunjukkan adanya kandungan terpenoid.

\section{Uji Saponin}

Uji Saponin dilakukan dilakukan masing-masing pada organ tumbuhan (akar, batang dan daun) dengan cara melarutkan $1 \mathrm{~mL}$ sampel dengan $1 \mathrm{~mL}$ akuades, kemudian diaduk selama 15 menit. Hasil positif kandungan saponin ditunjukkan dengan adanya buih yang stabil selama 5 menit.

\section{Uji Tanin}

Uji tanin dilakukan dilakukan masing-masing pada organ tumbuhan dengan cara melarutkan $1 \mathrm{~mL}$ sampel dengan $2 \mathrm{~mL}$ akuades. Selanjutnya ditambahkan 3 tetes larutan $\mathrm{FeCl} 3$. Terbentuknya warna biru kehitaman atau hijau kehitaman mengindikasikan posotif kandungan Tanin.

\section{Uji Fenol}

Uji kandungan fenol dilakukan dilakukan masing-masing pada organ tumbuhan dengan cara mencampur $3 \mathrm{~mL}$ sampel dengan 3 tetes $\mathrm{FeCl} 31 \%$. Terbentuknya warna hijau, merah ungu, biru atau hitam pekat mengindikasikan adanya kandungan fenol pada sampel.

\section{Analisis Data}

Analisis data pada penelitian ini merupakan analisi deskriptif kualitatif. Data identifikasi tanaman dideskripsikan secara kualitatif. Selanjutnya data hasil uji fitokimia tanaman ditandai dengan simbol (+) untuk menandakan bahwa ekstrak tersebut mengandung metabolit sekunder dan symbol (-) untuk menandakan bahwa ekstrak tanaman tidak mengandung metabolit sekunder.

\section{Hasil Dan Diskusi}

\section{Identifikasi Tanaman}

Identifikasi tanaman dilakukan untuk mengetahui jenis tanaman yang diuji pada penelitian. Tanaman tersebut terdiri dari dua jenis yang diperoleh dari Kawasan hutan Desa Laanoipi, Kecamatan Bonegunu, Kabupaten Buton Utara. Hasil identifikasi menunjukkan bahwa kedua merupakan tanaman yang tergolong ke dalam kelompok liana dengan ciri tumbuh merambat, memanjat atau mengantung.

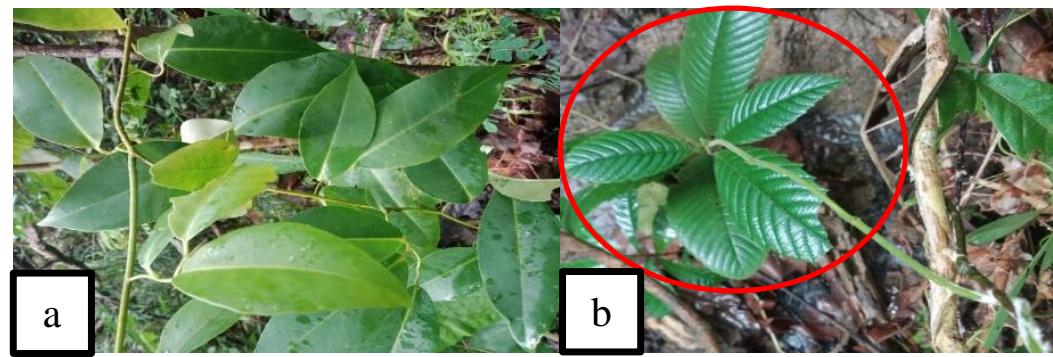

Gambar 1. a) Spesies Embelia sp.; b) Spesies Tetracera indica (Christm. \& panz. Merr.) 
e-Jurnal Ilmiah BIOSAINTROPIS (BIOSCIENCE-TROPIC)

Volume 7/ No.: 2 / Halaman 46 - 56 / Januari Tahun 2022

ISSN : 2460-9455 (e) - 2338-2805(p)

Hasil identifikasi tanaman yang diperoleh pada penelitian ini tercantum pada Tabel 1 .

Tabel 1. Hasil identifikasi tanaman

\begin{tabular}{|c|c|c|c|}
\hline No. & No. Kol. & Jenis & Suku \\
\hline 1 & Spesies 1 & Embelia sp. & Primulaceae \\
\hline 2 & Spesies 2 & $\begin{array}{c}\text { Tetracera indica } \text { (Christm. \& } \\
\text { panz. Merr. }\end{array}$ & Dilleniaceae \\
\hline
\end{tabular}

Hasil identifikasi tanaman menunjukkan bahwa tanaman yang digunakan dalam penelitian ini merupakan spesies Embelia sp. dan Tetracera indica (Christm. \& panz. Merr.). Ciri mrofologi tanaman seperti tercantum pada gambar berikut.
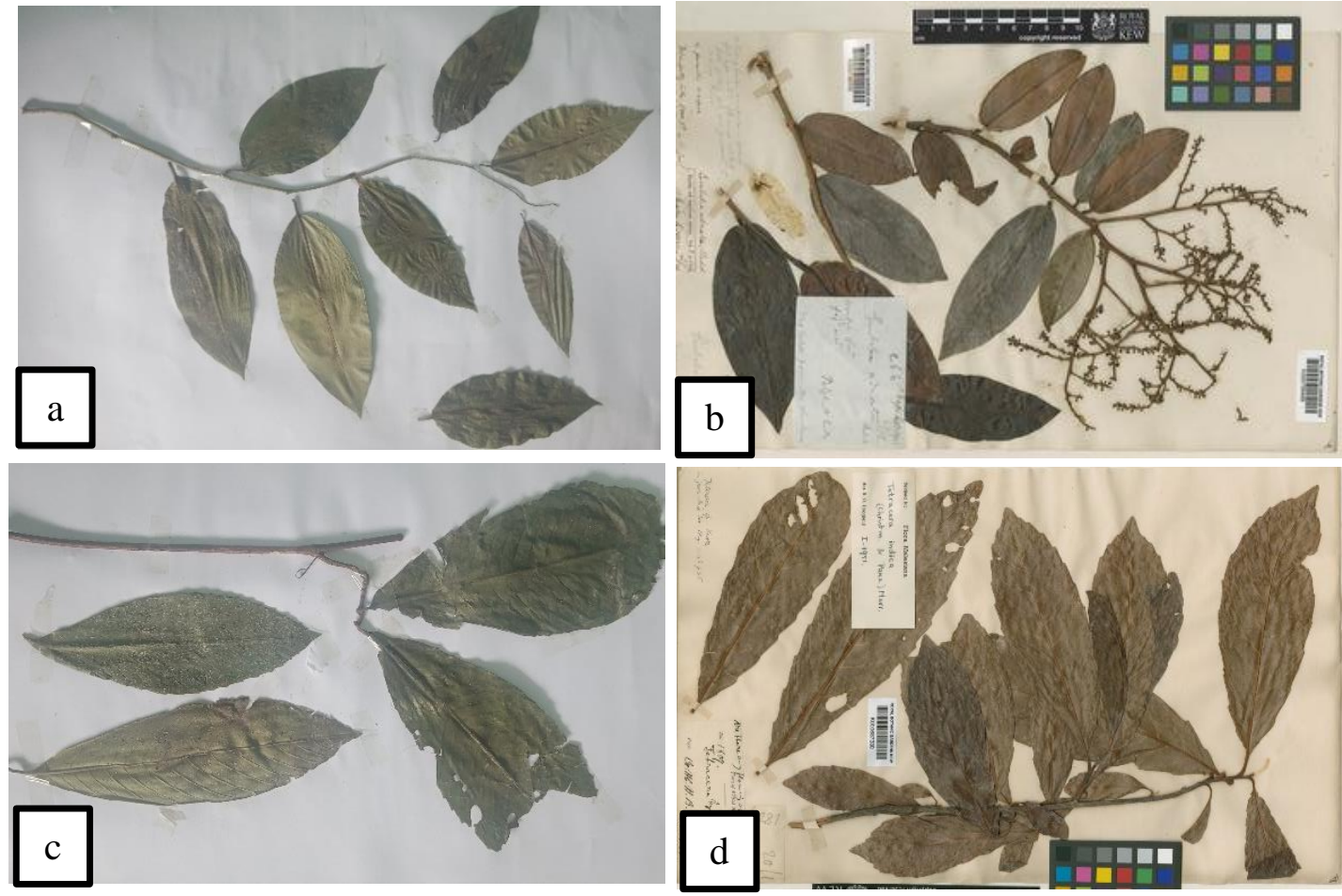

Gambar 2. a) sampel tanaman Embelia sp. b) spesimen pembanding, c) sampel tanaman Tetracera indica, d) spesimen pembanding

Ciri morofologi Embelia sp. diantaranya daun menempel pada batang dan tidak memiliki stipula, permukaan daun mengkilap, tulang daun menyirip dan ujung daun meruncing. Tanaman tumbuh memanjat dan memiliki duri yang tumpul pada bagian batang. Batang menghasilkan air yang jenrnih, air tersebut biasa digunakan untuk mengobati demam. Selanjutnya Tetracera indica memiliki ciri morfologi yakni daun berwarna hijau tua, pangkal daun runcing, prmukaan daun sedikit berambut, tepi daun bergerigi, urat daun menonjol, pangkal daun runcing, ujung daun meruncing, tangkai daun sedikit berambut dan memiliki daun tunggal, batang berkayu, bentuk batang bulat, permukaan batang kasar.

Embelia sp. menempati posisi yang cukup besar di bidang farmasi karena sejumlah kasiat obat telah tercatat. Spesies di bawah genus Embelia telah lama digunakan dalam praktek pengobatan tradisional seperti Ayurveda dan Siddha. Spesies di bawah genus Embelia memiliki aktivitas biologis seperti anthelmintik, karminatif, antibakteri, antibiotik, dan sifat hipoglikemik dan merupakan bahan dalam sekitar 75 formulasi obat Ayurveda tradisional [5]. Studi baru melaporkan bahwa potensi obat 
e-Jurnal Ilmiah BIOSAINTROPIS (BIOSCIENCE-TROPIC)

Volume 7/ No.: 2 / Halaman 46 - 56 / Januari Tahun 2022

ISSN : 2460-9455 (e) - 2338-2805(p)

dari genus ini memiliki sifat biologis seperti hepatoprotektif, analgesic, penghambatan amilase, penghambatan tripsin antibakteri, antikonvulsan, adaptogenik, antifertilitas, antikanker, antihiperlipidemia, antijamur dan anti-diabetes [6]. Di Buton Utara Embelia sp. lebih umum digunakan untuk obat demam dan penurun panas. Batang Embelia sp. menjadi sumber obat yang paling umum digunakan oleh masyarakat. Selanjutnya Tetracera indica (Christm. \& panz. Merr.) juga merupakan tanaman yang berkhsiat obat yang telah banyak di laporkan. Dalam pengobatan tradisional, daun Tetracera indicaa digunakan untuk mengobati diabetes di Malaysia [7] Di Musi Banyuasin merupakan salah satu obat tradisional yang digunakan masyarakat untuk pengobatan penyakit batu ginjal dan asam urat [8]

\section{Uji Fitokimia}

Uji fitokimia dilakukan pada dua jenis tanaman dan pada masing-masing organ tanaman yang meliputi akar, batang dan daun. Kandungan fitokimia yang diuji meliputi flavonoid, alkaloid, steroid, terpenoid, saponin, tanin dan fenol. Hasil uji fitokimia pada ektrak tanaman tercantum pada Tabel 1.

Hasil uji fitokimia pada penelitian ini tercantum pada Tabel 1.

\begin{tabular}{|c|c|c|c|c|c|}
\hline \multirow[t]{2}{*}{$\begin{array}{l}\text { Organ } \\
\text { Tanaman }\end{array}$} & \multirow[t]{2}{*}{ Senyawa Kimia } & \multicolumn{2}{|c|}{ Embelia sp. } & \multicolumn{2}{|c|}{$\begin{array}{c}\text { Tetracera indica (Christm. } \\
\text { \& panz. Merr.) }\end{array}$} \\
\hline & & Alkohol & Heksana & Alkohol & Heksana \\
\hline \multirow{7}{*}{ Akar } & Flavonoid & + & + & - & - \\
\hline & Alkaloid & + & + & + & + \\
\hline & Steroid & + & + & - & - \\
\hline & terpenoid & - & - & + & + \\
\hline & Saponin & + & + & + & + \\
\hline & Tanin & + & + & + & + \\
\hline & Fenol & + & + & + & + \\
\hline \multirow{7}{*}{ Batang } & Flafonoid & + & + & - & - \\
\hline & Alkaloid & + & + & + & + \\
\hline & Steroid & + & + & - & - \\
\hline & terpenoid & - & - & + & + \\
\hline & Saponin & + & + & + & + \\
\hline & Tanin & + & + & + & + \\
\hline & Fenol & + & + & + & + \\
\hline \multirow{5}{*}{ Daun } & Flafonoid & - & - & - & - \\
\hline & Alkaloid & + & + & + & + \\
\hline & Steroid & + & + & - & - \\
\hline & terpenoid & - & - & + & + \\
\hline & Saponin & + & + & + & + \\
\hline
\end{tabular}




\begin{tabular}{l|l|c|c|c|c}
\hline & Tanin & + & + & + & + \\
\cline { 2 - 6 } & Fenol & + & + & + & + \\
\hline
\end{tabular}

\section{Uji Flavonoid}

Hasil penelitian pada Tabel 1 menunjukkan bahwa akar dan batang tanaman Embelia sp. menunjukkan adanya kandungan flavonoid. Kandungan flavonoid ditandai dangan adanya perubahan warna merah. Namun, pada daun tidak menunjukkan adanya kandungan flavonoid. Hal ini ditandai dengan tidak adanya perubahan warna. Begitupula dengan hasil analisis pada Tetracera indica (Christm. \& panz. Merr.) tidak mengandung flavonoid. Flavonoid terdapat pada beberapa jenis tumbuhan seperti seperti pada tanaman Angiospermae. Flavonoid dapat berperan dalam penyerapan sinar ultra violet untuk mengarahkan serangga, pengaturan tumbuhan, pengaturan fotosintesis, kerja anti mikroba dan anti virus [9].

Flavonoid merupakan senyawa polifenol yang dibagi menjadi 6 kelompok: isoflavonoid, flavonon, flavonol, flavon, flavanol dan antosianidin yang ditemukan dalam berbagai jenis tanaman. Flavonoid telah terbukti memiliki berbagai macam efek antikanker. Flavonoid bekerja dengan cara menghentikan siklus sel, menginduksi apoptosis, autophagy, dan menekan proliferasi dan invasi sel kanker [10]. Semua kelompok flavonoid memiliki efek bagi Kesehatan misalnya isoflavonoid memiliki peran terutama dalam terapi kanker payudara dan prostat, penyakit kardiovaskular, serta untuk meminimalkan gejala menopause [11]. Flavanol dilaporkan berperan melindungi manusia dari penyakit pembuluh darah serta melindungi dari penuaan kognitif [12]. Flavanol dan flavanon telah terbukti bermanfaat dalam hal memberikan perlindungan saraf serta meningkatkan aliran darah otak [13]. Antosinidin memiliki aktivitas antioksidan dan antimikroba, meningkatkan kesehatan visual dan neurologis [14]. Kandungan flavonoid memungkinkan Embelia sp. dapat dimanfaatkan oleh masyarkat sebagai obat demam. Kandungan flavonoid pada tanaman dapat berkhasiat sebagai pereda demam (antipiretik) [15].

\section{Uji Alkaloid}

Hasil analisis menunjukkan bahwa kedua jenis tanaman mengandung alkaloid pada seluruh organ yang diuji. Alkaloid merupakan kelas senyawa organik yang mengandung nitrogen dan banyak ditemukan pada kingdom tumbuhan. Banyak alkaloid digunakan sebagai agen obat yang berharga yang dapat dimanfaatkan untuk mengobati berbagai penyakit seperti malaria, diabetes, kanker, dan disfungsi jantung. Pada tanaman sendiri, Alkaloid terutama terlibat dalam pertahanan tanaman terhadap herbivora dan patogen. Tanaman obat merupakan sumber yang kaya akan alkaloid, di mana memiliki aktivitas antiplatelet dan antikoagulan. Antiplatelet yang umum digunakan, aspirin, berasal dari salisin dan biasa digunakan dalam pengobatan nyeri [16]. Alkaloid dapat dimanfaatkan sebagai pengobatan seperti antiinflamasi, antimikroba, antijamur, analgesic, penghilang rasa sakit, neurofarmakologis, dan banyak aktivitas lainnya. Selain itu juga alkaloid berguna sebagai bahan diet, suplemen, dan obat-obatan dalam apalikasinya di kehidupan manusia [17].

\section{Uji Steroid}

Hasil uji steroid pada Embelia sp. menunjukkan positif kandungan steroid pada semua organ tanaman (akar, batang dan daun). Hal ini ditunjukkan dengan adanya perubahan warna menjadi hijau kebiruan. Namun pada Tetracera indica (Christm. \& panz. Merr.) menunjukkan hasil negatif steroid setelah dilakukan analisis kandungan steroid. Steroid merupakan salah satu jenis hormon yang diproduksi oleh kelompok tumbuhan dan hewan. Senyawa ini memainkan peranan penting dalam sistem biologis. Steroid mempengaruhi perkembangan tanaman seperti pembelahan sel, pertumbuhan akar, pertumbuhan pucuk, embrio, pembungaan, dan pertumbuhan tabung polen. Steroid dapat digunakan untuk mengobati gangguan inflamasi. Berdasarkan struktur kimianya, aktivitas farmakologis 
e-Jurnal Ilmiah BIOSAINTROPIS (BIOSCIENCE-TROPIC)

Volume 7/ No.: 2 / Halaman 46 - 56 / Januari Tahun 2022

ISSN : 2460-9455 (e) - 2338-2805(p)

dan sumbernya, steroid diklasifikasikan menjadi beberapa kelas yang berbeda yakni brassinosteroids, phytoecdysteroids, withanolides, cardenolides, dan bufadienolides [18]. Kelas steroid tersebut memiliki aktivitas pengobatan misalnya brassinosteroids dilaporkan memiliki aktivitas antikanker, antiangiogenik, antivirus, antigenotoksik, antijamur, dan antibakteri serta dapat menghambat replikasi virus dan menginduksi efek sitotoksik pada sel kanker [19]. Phytoecdysteroids memiliki efek pengobatan khususnya di bidang penyakit pengecilan otot dan diabetes [20]. Withanolides memiliki aktivitas adaptogenik, diuretik, anti-inflamasi, obat penenang / ansiolitik, sitotoksik, antitusif, dan imunomodulator [21]. Cardenolides berperan penting dalam pengobatan gagal jantung dan aritmia. Studi terbaru melaporkan bahwa cardenolides memiliki aktivitas dalam berbagai penyakit termasuk kanker, cystic fibrosis, atrofi otot spinobulbar [22]. Bufadienolides dilaporkan memiliki sifat kardioaktif dan aktivitas antikanker [23].

\section{Uji Saponin}

Hasil uji saponin pada Embelia sp. menunjukkan bahwa terdapat kandungan saponin pada organ akar dan batang. Hal ini ditunjukkan dengan terbentuknya buih setelah dilakukan uji. Sedangkan pada daun tanaman tidak menunjukkan adanya kandungan saponin. Selanjutnya, hasil analisis pada Tetracera indica (Christm. \& panz. Merr.) menunjukkan hasil positif saponin. Saponin adalah senyawa bioorganik alami yang memiliki setidaknya satu ikatan glikosidik (ikatan C-O-gula) pada C-3 antara aglikon dan rantai gula. Hidrolisis molekul saponin menghasilkan dua bagian, aglikon dan bagian gula [24]. Saponin dapat menghambat penyerapan kolesterol secara langsung dan tidak langsung di usus, sehingga dapat menurunkan kadar kolesterol dalam plasma darah dan empedu [25]. Selain itu, saponin dapat berperan anti-inflamasi, imunostimulan, hipokolesterolemia, hipoglikemik, antijamur dan sitotoksik serta dapat berperan dalam pengobatan obesitas [26].

\section{Uji Terpenoid}

Hasil penelitian pada tanaman Embelia sp. menunjukkan bahwa terpenoid tidak teridentifikasi pada ketiga bagian organ tanaman (akar, batang dan daun). Pada Tetracera indica (Christm. \& panz. Merr.) menunjukkan adanya kandungan terpenoid. Kandungan terpenoid ditunjukkan dengan adanya perubahan warna merah setelah dilakukan uji. Terpenoid merupakan kelas senyawa kimia yang ada di semua organisme hidup. Namun, tanaman hijau dan khususnya berbunga menunjukkan jumlah terpenoid yang lebih tinggi dibandingkan dengan organisme hidup lainnya. Berbagai penelitian telah memperkirakan bahwa jumlah senyawa terpenoid berbeda pada berbagai jenis tanaman. Hampir semua tanaman mensintesis terpenoid yang memiliki peranan penting seperti fitohormon, reagen modifikasi protein, anti oksidan dan lain lain [27]. Terpenoid di laporkan di sebagian besar tanaman herbal dan terbukti dapat dimanfaatkan sebagai obat malaria dan kanker [28]. Selain itu, terpenoid memiliki efek antitumor, antiinflamasi, antibakteri, antivirus, antimalaria, meningkatkan penyerapan transdermal, mencegah dan mengobati penyakit kardiovaskular, dan memiliki aktivitas hipoglikemik [29]. Studi literatur menunjukkan bahwa terpenoid memiliki efek hipotensi dan bradikardi serta menunjukkan aktivitas antioksidan, antikarsinogenik, antiinflamasi, antinosiseptif, antispasmodik, dan antidiabetogenic [30].

\section{Uji Tanin}

Hasil penelitian menunjukkan bahwa kedua jenis tanaman mengandung tanin, baik pada akar, batang dan daun. Tanin ditemukan di sebagian besar spesies tumbuhan. Tanin berfungsi untuk melindungi tanaman dari predasi dan untuk membantu mengatur pertumbuhan tanaman. Ada dua kelompok besar tanin yaitu tanin terhidrolisis dan tanin terkondensasi. Tanin telah dimanfaatkan sejak tahun 1960-an untuk berbagai macam kegunaan seperti produksi perekat di industri berbasis kayu, produksi kimia anti-korosif, kimia pemulihan uranium dari air laut, dan penghilangan merkuri dan metilmerkuri dari larutan. Saat ini tanin sedang dipertimbangkan sebagai senyawa bioaktif dalam ilmu 
e-Jurnal Ilmiah BIOSAINTROPIS (BIOSCIENCE-TROPIC)

Volume 7/ No.: 2 / Halaman 46 - 56 / Januari Tahun 2022

ISSN : 2460-9455 (e) - 2338-2805(p)

gizi [31]. Selain itu tanin berperan sebagai antioksidan dan antikarsinogen. Selain itu, ada banyak bukti bahwa tanin berperan penting sebagai anti-inflamasi, cicatrizant dan anti-HIV [32].

\section{Uji Fenol}

Fenolik adalah senyawa yang memiliki satu atau lebih cincin aromatik dengan satu atau lebih gugus hidroksil. Senyawa ini terdistribusi secara luas pada tumbuhan dan merupakan metabolit sekunder tumbuhan yang paling melimpah, dengan lebih dari 8.000 struktur fenolik yang saat ini diketahui. Fenolik tanaman umumnya terlibat dalam pertahanan terhadap radiasi ultraviolet atau agresi oleh pathogen, parasite dan predator serta berkontribusi pada warna tanaman. Fenol terdapat di semua organ tanaman dan merupakan konstituen luas dari makanan nabati bagi manusia [33]. Hasil penelitian menunjukkan bahwa Embelia sp. dan Tetracera indica (Christm. \& panz. Merr.) menunjukkan adanya kandungan fenol pada ketiga organ tanaman. Senyawa fenolik memiliki aktivitas antioksidan, antiinflamasi, anti-alergi, anti-karsinogenik, anti-hipertensi, kardioprotektif, antirematik dan antimikroba. Selain itu, memiliki efek pengobatan seperti kanker, penyakit kardiovaskular, diabetes, obesitas, dan penyakit menular termasuk infeksi virus, bakteri, dan protozoa [34].

\section{Kesimpulan}

Berdasarkan hasil penelitian yang diperoleh dapat disimpulkan bahwa :

1. Tanaman obat yang telah digunakan masyarakat Buton Utara sebagai obat merupakan spesies Embelia sp. dan spesies Tetracera indica (Christm. \& panz. Merr.)

2. Tanaman Embelia sp. mengandung flavonoid, alkaloid, steroid, tanin, dan fenol. Tanaman Tetracera indica (Christm. \& panz. Merr.) mengandung alkaloid, terpenoid, tanin, dan fenol. Flavonoid merupakan senyawa yang memungkinkan tanaman Embelia sp. dapat dimanfaatkan oleh masyarakat Buton Utara untuk mengobati demam. Serta kandungan terpenoid pada tanaman Tetracera indica (Christm. \& panz. Merr.), sehingga dapat dimanfaatkan sebagai obat tekanan darah tinggi

\section{Ucapan Terima Kasih}

Ucapan terima kasih kepada Universitas Muslim Buton yang telah menyediakan fasilitas untuk menunjang seluruh rangkaian pelaksanaan penelitian, sehingga penelitian ini dapat terselesaikan. Ucapan terima kasih pula kami haturkan kepada Kemeterian Riset, Teknologi dan Pendidikan Tinggi yang telah mendanai seluruh kegiatan penelitian, sehingga penelitian dapat terselesaikan sesuai target telah direncanakan.

\section{DAFTAR PUSTAKA}

[1] Y. . Henuk, "Understanding plant diversity and physiology for resilient production systems and environmental benefits," J. Plant Pathol. Microbiol., vol. 08, no. 05, p. 7471, 2017, doi: 10.4172/2157-7471-c1-004.

[2] W. Birhan, M. Giday, and T. Teklehaymanot, "The contribution of traditional healers' clinics to public health care system in Addis Ababa, Ethiopia: A cross-sectional study," J. Ethnobiol. Ethnomed., vol. 7, pp. 1-7, 2011, doi: 10.1186/1746-4269-7-39.

[3] D.- Suharjito, L. .- Darusman, D.- Darusman, and E.- Suwarno, "Comparing Medicinal Plants Use for Traditional and Modern Herbal Medicine in Long Nah Village of East Kalimantan," Bionatura, vol. 16, no. 2, pp. 95-102, 2014, [Online]. Available: http://journal.unpad.ac.id/bionatura/article/view/7570.

[4] B. B. Petrovska, "Historical review of medicinal plants' usage," Pharmacogn. Rev., vol. 6, no. 11, pp. 1-5, 2012, doi: 10.4103/0973-7847.95849. 
e-Jurnal Ilmiah BIOSAINTROPIS (BIOSCIENCE-TROPIC)

Volume 7/ No.: 2 / Halaman 46 - 56 / Januari Tahun 2022

ISSN : 2460-9455 (e) - 2338-2805(p)

[5] K. P. R. Vijayan and A. V. Raghu, "Embelin: an HPTLC method for quantitative estimation in five species of genus Embelia Burm. f.," Futur. J. Pharm. Sci., vol. 7, no. 1, 2021, doi: 10.1186/s43094-021-00210-w.

[6] K. Souravi and P. E. Rajasekharan, "A review on the pharmacology of Embelia ribes burm. F.A threatened medicinal plant," Int. J. Pharma Bio Sci., vol. 5, no. 2, pp. 443-456, 2014.

[7] Q. U. Ahmed et al., "Antidiabetic activity of the leaves of Tetracera indica Merr. (Dilleniaceae) in vivo and in vitro," J. Med. Plants Res., vol. 6, no. 49, pp. 5912-5922, 2012, doi: 10.5897/JMPR12.443.

[8] M. Muharni, E. Elfita, R. Adillah, H. Yohandini, and J. Julinar, "Flavon Compound from The Ethyl Acetate Extract of The Stem of Supit (Tetracera indica Merr.)," Molekul, vol. 13, no. 1, p. 38, 2018, doi: 10.20884/1.jm.2018.13.1.402.

[9] R. R. Radam and E. Purnamasari, "Uji Fitokimia Senyawa Kimia Aktif Akar Nipah (Nyfa Fruticans Wurmb) Sebagai Tumbuhan Obat Di Kalimantan Selatan,” J. Hutan Trop., vol. 4, no. 1, p. 28, 2017, doi: 10.20527/jht.v4i1.2879.

[10] D. M. Kopustinskiene, V. Jakstas, A. Savickas, and J. Bernatoniene, "Flavonoids as anticancer agents," Nutrients, vol. 12, no. 2, pp. 1-25, 2020, doi: 10.3390/nu12020457.

[11] S. Gómez-Zorita, M. González-Arceo, A. Fernández-Quintela, I. Eseberri, J. Trepiana, and M. P. Portillo, "Scientific evidence supporting the beneficial effects of isoflavones on human health," Nutrients, vol. 12, no. 12, pp. 1-25, 2020, doi: 10.3390/nu12123853.

[12] G. Gratton et al., "Dietary flavanols improve cerebral cortical oxygenation and cognition in healthy adults," Sci. Rep., vol. 10, no. 1, pp. 1-13, 2020, doi: 10.1038/s41598-020-76160-9.

[13] S. L. Gardener, S. R. Rainey-Smith, M. Weinborn, C. P. Bondonno, and R. N. Martins, "Intake of Products Containing Anthocyanins, Flavanols, and Flavanones, and Cognitive Function: A Narrative Review," Front. Aging Neurosci., vol. 13, no. September, pp. 1-14, 2021, doi: 10.3389/fnagi.2021.640381.

[14] H. E. Khoo, A. Azlan, S. T. Tang, and S. M. Lim, "Anthocyanidins and anthocyanins: Colored pigments as food, pharmaceutical ingredients, and the potential health benefits," Food Nutr. Res., vol. 61, no. 1, 2017, doi: 10.1080/16546628.2017.1361779.

[15] A. Suproborini, M. Soeprijadi, D. Laksana, and D. F. Yudiantoro, "Etnobotani Tanaman Antipiretik Masyarakat Dusun Mesu Boto Jatiroto Wonogiri Jawa Tengah Ethnobotany Antipyretic Plants Peoples in Dusun Mesu Boto Jatiroto Wonogiri Central Java," J. Pharm. Sci. Med. Res., vol. 1, no. 1, pp. 2614-6118, 2018.

[16] Q. U. Ain, H. Khan, M. S. Mubarak, and A. Pervaiz, "Plant alkaloids as antiplatelet agent: Drugs of the future in the light of recent developments," Front. Pharmacol., vol. 7, no. SEP, pp. 1-9, 2016, doi: 10.3389/fphar.2016.00292.

[17] J. Kurek, "Introductory Chapter: Alkaloids - Their Importance in Nature and for Human Life," Alkaloids - Their Importance Nat. Hum. Life, pp. 1-7, 2019, doi: 10.5772/intechopen.85400.

[18] S. S. Patel Assistant Professor, J. K. Savjani Assistant Professor, S. S. Patel, and J. K. Savjani, "Systematic review of plant steroids as potential anti- inflammatory agents: Current status and future perspectives," J. Phytopharm. JPHYTO, vol. 4, no. 42, pp. 121-125, 2015, [Online]. Available: www.phytopharmajournal.com.

[19] S. K. Kohli et al., "Therapeutic potential of brassinosteroids in biomedical and clinical research," Biomolecules, vol. 10, no. 4, 2020, doi: 10.3390/biom10040572. 
e-Jurnal Ilmiah BIOSAINTROPIS (BIOSCIENCE-TROPIC)

Volume 7/ No.: 2 / Halaman 46 - 56 / Januari Tahun 2022

ISSN : 2460-9455 (e) - 2338-2805(p)

[20] L. Dinan, N. Mamadalieva, and R. Lafont, "Dietary Phytoecdysteroids," In book: Handbook of Dietary PhytochemicalsPublisher: Springer, Singapore, 2020.

[21] K. Rharrabe, F. Sayah, and R. LaFont, "Dietary effects of four phytoecdysteroids on growth and development of the Indian meal moth, Plodia interpunctella," J. Insect Sci., vol. 10, no. 1, pp. 1-12, 2010, doi: 10.1673/031.010.1301.

[22] A. B. Krishna, H. K. Manikyam, V. K. Sharma, and N. Sharma, "Plant Cardenolides in Therapeutics," Int. J. Indig. Med. Plants, Sep. 2015.

[23] J. Kolodziejczyk-Czepas and A. Stochmal, "Bufadienolides of Kalanchoe species: an overview of chemical structure, biological activity and prospects for pharmacological use," Phytochem. Rev., vol. 16, no. 6, pp. 1155-1171, 2017, doi: 10.1007/s11101-017-9525-1.

[24] A. S. Ashour, M. M. A. El Aziz, and A. S. Gomha Melad, "A review on saponins from medicinal plants: chemistry, isolation, and determination," J. Nanomedicine Res., vol. 7, no. 4, pp. 282288, 2019, doi: 10.15406/jnmr.2019.07.00199.

[25] N. W. Bogoriani, I. B. Putra-Manuaba, and K. Suastika, "Cordyline Terminalis Kunth Leaves's Saponin Lowered Plasma Cholesterol And Bile Acids Levels By Increased The Excretion Of Fecal Total Bile Acids And Cholesterol In Male Wistar Rats," Eur. J. Biomed. Pharm. Sci., vol. 2, no. 5, pp. 122-134, 2015.

[26] M. Marrelli, F. Conforti, F. Araniti, and G. A. Statti, "Effects of saponins on lipid metabolism: A review of potential health benefits in the treatment of obesity," Molecules, vol. 21, no. 10, 2016, doi: 10.3390/molecules21101404.

[27] E. Pichersky and R. A. Raguso, "Why do plants produce so many terpenoid compounds?," New Phytol., vol. 220, no. 3, pp. 692-702, 2018, doi: 10.1111/nph.14178.

[28] K. Negi, S. Singh, M. S. Gahlot, S. Tyagi, and A. Gupta, "Terpenoids from medicinal plants beneficial for human health care: Review Terpenoids from medicinal plants beneficial for human health care : Review," Int. J. Bot. Stud., vol. 5, no. 4, pp. 135-138, 2020.

[29] W. Yang, X. Chen, Y. Li, S. Guo, Z. Wang, and X. Yu, “Advances in Pharmacological Activities of Terpenoids," Nat. Prod. Commun., vol. 15, no. 3, 2020, doi: 10.1177/1934578X20903555.

[30] A. Cardoso-Teixeira, K. Abreu, L. Brito, A. Coelho-de-Souza, and J. Leal-Cardoso, "Effects of Terpenes and Terpenoids of Natural Occurrence in Essential Oils on Vascular Smooth Muscle and on Systemic Blood Pressure: Pharmacological Studies and Perspective of Therapeutic Use," 2020.

[31] R. D. Das, A.K., Md. Nazru Islam, Md. Omar Faruk, Md. Ashaduzzaman, "Review on tannins: Extraction processes, applications and possibilities," South African J. Bot., vol. 135, pp. 58-79, 2020, doi: https://doi.org/10.1016/j.sajb.2020.08.008.

[32] C. M. Furlan, L. B. Motta, and and D. Y. A. C. dos Santos, "T ANNINS : W HAT D O T HEY R EPRESENT IN P LANT L IFE ?,” no. May 2014, 2011.

[33] J. Dai and R. J. Mumper, "Plant phenolics: Extraction, analysis and their antioxidant and anticancer properties," Molecules, vol. 15, no. 10, pp. 7313-7352, 2010, doi: 10.3390/molecules15107313.

[34] D. J. Bhuyan and A. Basu, "Phenolic compounds: Potential Health Benefits and Toxicity," no. August, In book: Utilisation of Bioactive Compounds from Agricultural and Food Production Waste (pp.27-59) Publisher: CRC Press, Taylor \& Francis Group, 2017. 